\title{
CONFLICT AVOIDANCE IN PRACTICE AND THEORY
}

\author{
Clive M. SchmitthofF*
}

\section{I}

\section{The Problem of Conflict Avoidance}

\section{A. Conflict Avoidance and Conflict Solution}

The conflict of laws differs from all other branches of private law in concept and content: while the raison d'être of all other branches of private law is in natural human activities and motives, and those branches of law are concerned with the regulation of social functions resulting directly from human relations, the conflict of laws has its origin in the diversity of the laws existing in various territorial legal units and is the artificial product of the law itself. It is natural that people should wish to set up families, to own property, to trade, and even that they should commit torts and crimes. The social problems resulting from these human activities are regulated by family law, the law of real and personal property, commercial law, the law of torts, and criminal law. A conflict-of-laws problem, on the other hand, is a complication imported into human and social relations by the extraneous fact that the laws of different legal units offer different solutions to problems arising in one of the primary branches of law. To the layman, the necessity of legal norms regulating family relations, property, contract, torts, and crimes will be obvious, but he will realize the necessity for the existence of a secondary branch of law, such as a system of conflict norms, only after some explanation and meditation.

The avoidance of conflict situations has always been regarded as one of the major objectives of the law. In the conflict of laws, two approaches are possible to the disposal of a conflict problem: the preventive method of conflict avoidance and the clinical method of conflict solution. The aim of the former is to avoid a situation in which a conflict of laws is likely to arise, by the use of a localization or other avoidance device. Conflict solution, on the other hand, is concerned with the judicial or legislative solution of a conflict problem which has arisen in a particular legal relationship; the aim here is to provide rules which dispose of the conflict issue in a smooth and just manner. It is obvious that every municipal system of conflict rules combines elements of conflict avoidance and conflict solution, and, further, that conflict avoidance can be practiced mainly in areas governed by facultative legal norms-i.e., in the province of the autonomy of the parties-while conflict solution is

- LL.D., Universities of London and Berlin. Of Gray's Inn, Barrister-at-Law; Lecturer in Legal Studies, The City of London College. Author, The English Conflict of Laws (3d ed. 1954); The Export Trade (3d ed. I955); The Sale of Goods (I951); Legal Aspects of Export Sales (1953). Joint Editor, ChitTy, Contracts (2Ist ed. I955). General Editor, Business Law and Administration (1951); The Business Law Review. 
normally the only method by which problems arising in the area of compulsory, as opposed to facultative, norms can be disposed of.

The distinction between conflict avoidance and conflict solution requires further amplification. It is clear that a choice-of-law clause in a contract is a typical avoidance device, though, in the eyes of the modern commercial lawyer, in some instances, a crude and only partially effective one. It is equally clear that a normal conflict dispute-e.g., the question whether a charter-party in the English language and form, under which an Italian ship is chartered by French charterers for the carriage of goods from a French to an Italian port, is governed by Italian, French, or English law ${ }^{1-i s}$ a question of conflict solution. Similar is the position with respect to statutes. An act ${ }^{2}$ giving effect to an international convention, such as the Carriage of Goods by Sea Act, $1924,{ }^{3}$ or the Carriage by Air Act, $1932,{ }^{4}$ is-like the international convention itself -an instrument of conflict avoidance; while enactments such as the Wills Act, $186 \mathrm{I}^{\tilde{3}}$ (Lord Kingsdown's Act), or section 72 of the Bills of Exchange Act, $1882,{ }^{6}$ provide solutions for conflict problems in contentious and noncontentious matters. Sometimes a statute may serve both purposes. Thus, the Matrimonial Causes Act, $1950,{ }^{7}$ provides in section $18(3)$ that in proceedings for the dissolution of a marriage instituted in the English courts by a wife satisfying certain residential qualifications, issues of substantive law shall be determined in accordance with "the law which would be applicable thereto if both parties were domiciled in England at the time of the proceedings"; this provision serves both the general purpose of avoidance and the special one of solution in a particular conflict issue.

The relation between the avoidance and the solution of conflict problems is naturally close. The practitioner who plans a conflict-avoidance device has to study the sources of conflict solution that he will find in the statute book, the law reports, and textbooks; and, since various legal systems are involved, he has to be well versed in the comparative method if he wishes to make the avoidance device truly effective.

Traditionally, the conflict systems of the common-law countries are essentially founded on rules of conflict solution, and little emphasis is laid on conflict avoidance. This is attributable to the fact that the common-law jurist regards judicial pronouncements as the main source of law and considers it his task to construct upon them a logical system of legal prescripts, except in areas covered by statutes, which, in the province of the conflict of laws, are few and far between. This preoccupation with conflict solution obscures, however, the reality of the practitioner's work in matters likely to lead to a conflict of laws. Counsel advising on an export or import transaction, on international monetary obligations, on the international organization of corporate business, on the creation and management of international public utili-

\footnotetext{
I These are the facts of The Assunzione, [1954] P. 150 (C. A.), in which, incidentally, it was held that Italian law applied.

2 All references are to United Kingdom acts unless stated otherwise.

314 \& 5 GEO. 5, c. 22.

$52 \& 25$ VICT. c. II4.

$422 \& 23$ Geo. 5 , c. 36.

7 I GEo. 6, c. 25.

${ }^{\circ} 45$ \& 46 VICr. c. 6I.
} 
ties, on trusts of movable property or on succession planning having a foreign complexion, on insurance and reinsurance extending over several jurisdictions, on world air law, or on the international protection of patents, trade marks, or other industrial and artistic property is at least as concerned with the avoidance of a conflict situation as with conflict solution. His problem is to provide sufficient legal -and sometimes extralegal-safeguards to prevent the transaction which he has to plan from foundering on the rocks of a national conflict system.

Moreover, three tendencies in the general political and economic development in the years following the Second World War have created an atmosphere favorable to conflict avoidance. First, in western Europe, the rigid system of national sovereignties, which in the nineteenth and first half of the twentieth century gave rise to an overrefinement of modern conflict law, has begun to soften up and to give way to the grouping of states in supranational regional organizations. ${ }^{8}$ Secondly, international corporations of one sort or another are making an increasingly insistent appearance in modern economic life. ${ }^{9}$ Hereunder fall not only governmental agencies, such as the Bank of International Settlement, the Bank for International Reconstruction and Development, the International Monetary Fund, and the European Coal and Steel Community, but likewise corporate bodies which constitutionally are closer to the ordinary national business corporation. Thus, as Professor Batiffol informs us, ${ }^{10}$ the project of a European company enjoying corporate status in all countries which are members of the Council of Europe is, at present, under consideration. These companies, which will have as members citizens or governments of different countries, will be used for holding concessions in the nature of public utilities extending over several European countries, and European status will be conferred on them by a convention concluded between the countries directly interested in the company. From the functional point of view, international public corporations, private corporations granted international status, and foreign corporations of the traditional type are all instruments of conflict avoidance, although operating on different levels. Thirdly, as the result of the development of modern aviation, telecommunications, and nuclear power, the world is rapidly assuming parochial character, and a situation is created in which the social and commercial contacts between nations and their citizens are becoming much closer than ever before in the history of mankind. These developments will influence the practical and theoretical character of all national conflict systems; they will lead to a greater

\footnotetext{
s The Treaty Relating to a Uniform Law on the Conflict of Laws, concluded at the Hague between Belgium, the Netherlands, and Luxembourg on May II, I95I (the so-called Benelux Treaty, not yet in force), and the five Draft Conventions accepted by the Seventh Session of the Hague Conference on Private International Law are encouraging signs in that direction. See Clive M. Schmitrhoff, The ENGLish Conflict of Laws I7 (3d ed. 1954).

${ }^{\circ}$ On public international corporations, see Friedmann, The International Public Corporation, 6 MOdern L. Rev. 185 (1943); Schmithoff, The International Corporation, 30 Transactions of the Grotrus Societry 165 (1944); Parry, The International Public Corporation, in The Public Corporanon 495 (Friedmann ed. 1954).

${ }^{10}$ Batiffol, Conflict Atoidance in European Laty, infra $57 \mathrm{x}-80$.
} 
emphasis upon conflict avoidance than has been attributed to this discipline hitherto. In the practice of private international law, conflict avoidance, particularly on the international and the private level, will become a discipline equal in status to that of conflict solution. In the theory of the conflict of laws, due recognition of conflict avoidance may possibly open a new perspective of the subject and encourage a more modern and less historically conditioned approach to it.

\section{B. Levels of Conflict Avoidance}

Conflict avoidance can be pursued on three levels: international, national, and private.

\section{Conflict on the International Level.}

Conflict avoidance on this level assumes two forms: states may enter into an international treaty or convention by which they undertake to introduce uniform legislation and may give these international agreements legislative force in their municipal jurisdictions; or nongovernmental bodies, such as the International Law Association or the International Chamber of Commerce, may suggest uniform rules for general adoption by business associations or for incorporation by individual contracting parties into their contracts.

Illustrations of international conventions aiming at uniformity of law are the Brussels Convention of rg24, adopting the Hague Rules of rg2I on Bills of Lading; the Warsaw Convention of 1929 for the Unification of Certain Rules Relating to International Carriage by Air, which it is proposed to amend by the Draft Protocol of September 28, I955, adopted by the Hague Conference of Members of the Warsaw Union and the International Civil Aviation Organization (I.C.A.O.) ${ }^{11}$ the Protocol on Arbitration Clauses, I923, and the Convention on the Execution of Foreign Arbitral Awards of 1927; ${ }^{12}$ the Geneva Uniform Laws of Negotiable Instruments of $193^{\circ}$ and $193{ }^{13}$ and the draft of a uniform law concerning international sales of goods proposed by the Rome Institute for the Unification of Private Law. ${ }^{14}$ Illustrations of rules suggested by international nongovernmental bodies for adoption by trade associations or individual contracting parties are the York-Antwerp Rules, $1950,{ }^{15}$ of the International Law Association; or Incoterms, ${ }^{16}$ and Uniform Customs and Practice for Commercial Documentary Credits, ${ }^{17}$ both sponsored by the International Chamber of Commerce.

The fundamental distinction between these two types of conflict avoidance on the

${ }^{11}$ See Verplaetse, Proposed Changes in the Laiv of Carriage by Air, 3 Bus. L. Rev. 95 (1956).

${ }^{19}$ See the Arbitration Act, 1950, 14 Geo. 6, c. 27.

${ }^{13}$ Which are given legislative force in many European countries, but not in the United Kingdom.

${ }^{16}$ See Gutteridge, An International Code of the Latu of Sale, I4 BRIT. Y. B. INT'L L. 75 (1933), and The Unification of Private Law, 20 Brit. Y. B. INT'L L. 37 (I939); ERNST RABEL, DAs RechT DES WARENKAUFS (1936).

${ }^{15}$ See Richard Lowndes and G. R. Rudolf, The law of Gengral averages and the York: ANTwerp Rules (8th ed. 1955).

${ }^{10}$ InTERNATIONAL Chamber OF COMMerce, INCOTERMS (x953).

${ }^{17}$ International Chamber of Commerce, Uniform Customs and Practice for Commercial Documentary Credits (I95I Revision). 
international level is that the former has a binding effect on parties in the various countries which have embodied these measures into their municipal legislation, and in so far, the inaccurate but descriptive phrase "international legislation" is justified; whereas measures of the latter type are, on principle, ${ }^{18}$ within the autonomy of the contracting parties and do not apply unless adopted by them.

Gutteridge classifies the attempts at unification of law in the international sphere into

a. complete or incomplete,

b. bilateral, multilateral, or regional,

c. internal or external, and

d. entire or partial,

and explains these distinctions in the following passage: ${ }^{19}$

It may be complete or incomplete, according to the extent to which it has been found possible to unify all the conflicting rules or, as the case may be, to secure the adoption of the unified rules by all of the countries concerned. It may also be bilateral or multilateral. Bilateral unification is confined to the laws of two countries, whilst multilateral unification embraces the laws of several countries. Where the process is confined to the rules of certain neighbouring countries it is sometimes referred to as regional unification. There are many other aspects of unification. It may, for instance, be internal or external; in the first case its object is to do away with conflicts of law existing within the territorial area of a single state; in the second case it is designed to secure uniformity of rule between the laws of several states. Examples of internal unification are to be found in the Uniform Laws of the United States and in the Swiss codes, and of external unification in the Brussels Conventions on Maritime Law and the Geneva Uniform Laws on Negotiable Instruments. Unification may also be entire or partial. If it is entire, the various systems concerned abandon their national rules and adopt the unified rules for all purposes. If it is partial, each system retains its own rules for the purpose of adjudication in disputes of a domestic character, and confines the application of the unified rules to disputes containing some foreign element, such as the residence of the parties in different jurisdictions or the situation of the subject-matter of the dispute in a foreign country. The Geneva Uniform Laws on Negotiable Instruments illustrate "entire" unification, whilst the Warsaw Convention of 1929 on the Carriage of Goods by Air affords an example of "partial" unification.

Gutteridge mainly analyzes the nature and characteristics of unified law and explains the mechanism of unification ${ }^{20}$ but notes the effect of unified law as a means of conflict avoidance merely in passing. ${ }^{21}$ A clear indication of that effect is contained in Professor Vallindas' Autonomy of International Uniform Law: ${ }^{22}$

As is, the substantive sphere of International Uniform Law extends, prima facie, over municipal law and does not encompass international law, but-and here it differs from

${ }^{18}$ In practice, this autonomy is limited in the cases in which recommendations of international nongovernmental bodies have been accepted by trade associations which impose on their members a duty. to adopt the recommendations. See infra 439 .

${ }^{10} \mathrm{H}$. C. Gutteridge, Comparative Law 154-55 (1946).

${ }^{20} \mathrm{Id}$. at $145-84$.

21 Id. at 154 .

228 Revue Hellénique de Droit International 8, 9 (1955). 
private international law-International Uniform Law does not attempt to regulate international intercourse by harmonizing the co-existence of differing municipal laws. On the contrary, it aims at the elimination of the differences themselves.

This observation that international uniform law aims at the "elimination of the differences" between municipal laws is a clear recognition of the character of that type of law as a means of conflict avoidance. Professor Vallindas makes an eloquent plea for the teaching of international uniform law: he suggests that it should become a "new and separate branch of legal research and instruction" and should be taught on an "independent basis."23 While the present writer respectfully agrees that the teaching of the principles and procedure of international uniform law is a matter of great importance, it is thought that this branch of law forms part of the broader discipline of conflict avoidance and should be included into what Professor Vallindas calls private international law lato sensu. ${ }^{24}$

\section{Conflict Avoidance on the National Level.}

That statutes of a sovereign exercising jurisdiction over several legal units aim at conflict avoidance on an internal level is a fact too well known to require elaboration. In the United States of America, this tendency is evinced by measures as dissimilar in nature as the "full faith and credit" clause of the Constitution ${ }^{25}$ and the attempts at securing adoption of uniform laws in the various state jurisdictions, of which the Uniform Commercial Code ${ }^{26}$ is a recent example. In the British Commonwealth, legislation corresponding to the United Kingdom British Nationality Act, $\mathrm{x} 948,{ }^{27}$ is adopted by the self-governing dominions; ${ }^{28}$ and in the United Kingdom itself, examples of unified legislation are provided by the Factors Acts and the Sale of Goods Act, $\mathrm{x} 893{ }^{20}$

Conflict avoidance on the national level is further practiced by the national courts. Since an international convention adopted by national legislations does not normally provide that disputes between private litigants relating to the interpretation of the convention shall be decided by a forum commune, it depends on the interpretation of the convention in the national courts of the signatories whether the unity of law is maintained or wholly or partially lost. The national courts are, thus, the guardians of international unity of law. The English courts are fully aware of this problem

${ }^{23}$ Id. at 13 .

3t Id. at I2.

${ }^{25}$ U. S. Const. art. IV, § I.

${ }^{28}$ For extended critical discussion of this proposed legislation, see the symposium at 16 LAw \& Contemp. Pros. I-343 (195I).

${ }^{27} 11$ \& 12 GEO. 6 , c. 56 .

${ }^{28}$ E.g., Ceylon Citizenship Act, No. 18 of 1948; Canadian Citizenship Act, 1946, 10 Gro. 6, c. 15; Australian Nationality and Citizenship Act, No. 83 of 1948; New Zealand Citizenship Act, No. 15 of 1948; South African Citizenship Act, No. 44 of 1949.

${ }^{20} 56$ \& 57 Vict. c. 7I. The Factors Act, I889, 52 \& 53 VICr. c. 45, does not extend to Scotland, but, by the Factors (Scotland) Act, 1890, 53 \& 54 Vicr. c. 40, was so extended; and the original Sale of Goods Bill of $189 \mathrm{x}$ did not apply to Scotland, but later, after some adaptation, was extended to that part of the United Kingdom. The Act of 1893 , thus, unified the sales law of the whole of the United Kingdom. 
and so, when called upon to interpret a statute embodying uniform international legislation, will interpret it in the interest of uniformity as far as the English rules relating to the construction of statutes allow. Thus, Lord Macmillan said in Stag Line v. Foscolo Mango, a case concerned with the interpretation of the Hague Rules embodied in the Carriage of Goods by Sea Act, $1924:^{30}$

It is important to remember that the Act of 1924 was the outcome of an International Conference and that the rules in the Schedule have an international currency. As those rules must come under the consideration of foreign Courts it is desirable in the interests of uniformity that their interpretation should not be rigidly controlled by domestic precedents of antecedent date, but rather that the language of the rules should be construed on broad principles of general acceptation.

And Lord Atkin said in the same case: ${ }^{31}$

For the purpose of uniformity it is, therefore, important that the Courts should apply themselves to the consideration only of the words used without any predilection for the former law, always preserving the right to say that words used in the English language which have already in the particular context received judicial interpretation may be presumed to be used in the sense already judicially imputed to them.

Similar rules of construction apply where an Act of Parliament of the United Kingdom might be interpreted differently in the English and the Scottish courts. Lord Goddard, C. J., observed in one case: $:^{32}$

It is no doubt desirable that where an Act of Parliament applies on both sides of the border the constuction placed on it by the courts in both countries should be the same.

Another interesting illustration of conflict avoidance on the national level occurred in Inland Revenue Commissioners v. City of Glasgow Police Athletic Association, $^{33}$ where the House of Lords, in an appeal from Scotland, held that the English law of charities, for the purposes of income tax legislation and for them alone, had to be regarded as part of the law of Scotland and not as foreign-i.e., Englishlaw. The English law of charities had, therefore, not to be proved as a fact in the Scottish courts.

The instances of conflict avoidance on the national level can, thus, be arranged in three classes: avoidance of an internal conflict between the laws of several legal units under the jurisdiction of the same sovereign; avoidance of loss of international uniformity by the different national interpretation of international agreements; and avoidance by an express provision that a particular law shall apply-e.g., in the Glasgow Police Athletic Association case, the English law of charities qua Scots law, and

${ }^{80}$ [1932] A. C. $328,350$.

${ }^{32}$ Id. at 343. On the general construction of the Carriage of Goods by Sea Act, 1924, by the English courts, see Thomas E. Scrutton, Charterparties and Bills of Lading 458 (16th ed. I955); R. P. Colinvaux, The Carriage of Goods my SeA ACT, 1924, at 20 (1954). On the reference to the French text of the Hague Rules, see further Singleton, L. J., in G. H. Renton \& Co. Itd. v. Palmyra Trading Corp. of Panama, [1956] 2 Weekly L. R. 232, 250.

${ }^{33}$ Newman v. Lipman, [195r] r K. B. 333, 337. The learned judge repeated the same observation in Cording v. Halse, [1955] I Q. B. 63, and Watson v. Nikolaisen, [1955] 2 Q.B. 286.

${ }_{33}^{3}$ [1953] A. C. $380,393$. 
under section I8(3) of the Matrimonial Causes Act, 1950, which was mentioned earlier, English law as the substantive law of the divorce.

It is tempting to include into the subject of judicial conflict avoidance the many instances in which the courts, when deciding an issue, are guided by the desire to avoid different decisions in different jurisdictions. The modern rule of reciprocity with respect to divorce proceedings, developed by the English Court of Appeal in Travers v. Holley, ${ }^{34}$ and applied by Barnard, J., in Carr v. Carr, ${ }^{35}$ is an illustration of this tendency. According to the rule in Travers v. Holley, the English courts will recognize a divorce decree of a foreign court which is not the court of matrimonial domicile but which founds its jurisdiction on a residential qualification of the wife that is substantially the same as the residential qualifications provided by the English statute law. ${ }^{36}$ That the courts, when deciding a conflict issue, should aim at avoiding a different solution of the same conflict problem in different jurisdictions, is neither new nor surprising. The same tendency is noticeable in the well-known rule that in certain cases, the English courts abandon, in conflict matters, the municipal classification of property into real and personal property and adopt the classification into movable and immovable property, "in order to arrive at a common basis"37 with other systems of jurisprudence. However, these problems pertain to conflict solution, and not to conflict avoidance in the sense in which that term is used here.

\section{Conflict Avoidance on the Private Level.}

This is the domain of the legal practitioner engaged in the planning of business or other transactions having a foreign complexion. While international conflict avoidance is the preserve of jurists, governments, and legislators, conflict avoidance in commercial and other relations of private law is regarded by the practitioner as the field of preventive law of conflicts par excellence.

On the private level, conflict avoidance is founded on the principle of party autonomy, which most, but not all, national laws admit with respect to many legal transactions. A lawyer intent on introducing a localization or other avoidance device into a legal transaction has first to ascertain the extent to which party autonomy is admitted in the various jurisdictions with which the transaction is connected. As Professor Yntema points out, in some countries (England, France, Germany, Italy, and others), the concept of party autonomy is fairly wide, while in others it is restricted (the Latin American countries, except Brazil), doubted (the Netherlands), or rejected (apparently Russia). ${ }^{38}$ Characteristic of the restrictive tendency is the regulation of article 5 of the Additional Protocol to the Treaties of Montevideo of

\footnotetext{
${ }^{34}$ [1953] P. 246 (C. A.). ${ }^{35}$ [1955] I Wcekly L. R. 422.

${ }^{86}$ But this rule does not apply where the forcign requirements as to residence are not the same as in English law. Dunne v. Saban, [1955] P. I78.

${ }^{37}$ Per Farwell, J., in Re Hoyles, [I9II] I Ch. 179, 185 (C. A.); sec also Pearson, J., in Jabbour v. Custodian of Israeli Property, [1954] I Weelly L. R. 139, 149.

${ }^{38}$ Yntema, "Autonomy" in Choice of Law, I AM. J. Comp. L. $34 \mathrm{I}$ (1952); Contract and Conflict of Laws: "Autonomy" and Choice of Law in the United States, 1 N.Y.L. Forum 46 (1955).
} 
1940, which provides that the jurisdiction and the law applicable by virtue of the treaties shall not be modified by the will of the parties except as such law authorizes. Professor Yntema rightly observes that the regulation of article 5 "is designed to remove the question of autonomy from conflicts law to be decided in accordance with the indicated domestic law."39

It is interesting to note that conflict avoidance in matters of contract may be practiced both in the field of party autonomy and in that of restriction or exclusion of it. In the former, it is carried out on the private level-e.g., by adoption of a choice-of-law clause-and in the latter, it may be done on the international or national level, as is demonstrated by the position under the Additional Protocol and the Russian solution, respectively.

In England, as far as contracts are concerned, a liberal and very wide interpretation is given to the concept of party autonomy. The locus classicus is the famous statement of Lord Atkin in Rex v. International Trustee:40

The legal principles which are to guide an English Court on the question of the proper law of a contract are now well settled. It is the law which the parties intended to apply. Their intention will be ascertained by the intention expressed in the contract, if any, which will be conclusive. If no intention be expressed the intention will be presumed by the Court from the terms of the contract and the relevant surrounding circumstances.

This statement has been quoted in many decisions, particularly of recent date. ${ }^{41}$ The theoretical dispute whether the doctrine of the proper law is founded on the subjective, or intention, theory or the objective, or connection, theory is decided by the English courts in favor of the former, which means, in practice, that the parties are at liberty to elect any legal system-even if unconnected with the contract-provided their choice is bona fide and not contrary to the public policy of the lex fori. ${ }^{42}$ The adoption of the subjective theory is a matter of commercial necessity in England since many merchants from overseas submit contracts to arbitration by English international commodity associations, although, apart from the adoption of the English contract in which the arbitration clause occurs, the transaction has no connection with England.

The concept of party autonomy, where admitted in a municipal conflict system, applies not only to the choice of the proper law of contract, but likewise, though to a limited and qualified extent, to inter vivos trusts of movables ${ }^{43}$ and succession planning. ${ }^{44}$ Moreover, that concept exists likewise in the law of corporations. Where
${ }^{30} \mathrm{Id}$. at 350 .
${ }^{10}$ [1937] A. C. 500,529 .

${ }^{12}$ E.g., The Metamorphosis, [1953] I Weekly L. R. 543, 547; The Assunzione, [1953] I Weekly L. R. 929, 932; [x954] 2 Weekly L. R. 234, 249, 254, 26I; [I954] P. 150 (C. A.); N. V. Handel My J. Smits Import-Export v. English Exporters, [1955] 2 Lloyd's Rep. 69.

${ }^{4}$ Vita Food Products Inc. v. Unus Shipping Co., [1939] A. C. 277 (P. C.) On the subjective and the objective theory, see Schmirthoff, op. cit. supra note 8 , at I07.

${ }^{4}$ For a more detailed discussion of this aspect, see Dean, Conflict Avoidance in Inter Vivos Trusts of Movables, infra $483-98$.

"This matter is developed more extensively elsewhere in this symposium. See Scoles and Rheinstein, Conflict Avoidance in Succession Planning, infra 499-532. 
a corporation intends to extend its activities to a country other than that in which it is incorporated, normally two courses are open to it: either it may operate in that other territory as a "foreign company"-e.g., in the United Kingdom, after having established a place of business within the jurisdiction, it becomes an "oversea company," ${ }^{45}$ which has to register certain particulars, file balance sheets with the English Registrar of Companies, and comply with other statutory requirements; or it may incorporate a so-called "foreign subsidiary"46 in the other territory and exercise proprietary or managerial control, or both, over it.

Further, a considerable degree of party autonomy exists in the choice of the forum in which legal proceedings are taken. It is well known that the lex fori normally governs matters of procedure and that that rule leaves little room to party discretion. That, however, is not meant here. It is the choice of the forum itself which is often within the discretion of the parties. Thus, the plaintiff has a choice of forums where an international monetary obligation provides for several loci solutionis. For example, in Rex $v$. International Trustee, there were in issue $5 \frac{1}{2} \%$ Gold Dollar Bonds of the United Kingdom which were repayable in New York or, at the option of the holder, in London. In view of the Joint Resolution of Congress of June 5 , I933, declaring payment on a gold basis of an obligation containing a gold clause as contrary to public policy, ${ }^{47}$ the bondholder who commenced proceedings obviously preferred the English to the American forum. Further, it may happen that the plaintiff can recover in one forum damages which would be regarded as too remote in another forum ${ }^{48}$ or that an arbitration clause; undoubtedly valid in one forum, may be held to be invalid in another. ${ }^{49}$ The defendant is often faced with the difficult practical problem whether he shall submit to the jurisdiction of a court which is internationally incompetent, but in which the plaintiff commenced proceedings; or whether it might be wiser to ignore those proceedings and to defend the case only in his own forum if the foreign court gives judgment against him and the other party attempts to bring an action on it or to execute it. ${ }^{50}$

Most countries place a number of limitations on the automony of the parties' will. Professor Yntema, who examines this problem, has listed and discussed nine of these

45 For the definition of an oversea company, see Companies Act, I948, II \& 12 GEo. 6, c. $38, \$ 406$.

40 The foreign subsidiary as localization device is treated infra $450-53$.

17 Act of June $5, x 933$, c. $48, \S$ I, 48 STAT. Ir3, 3I U. S. C. $\$ 463$ (1952).

${ }^{\star s}$ See N. V. Handel My J. Smits Import-Export v. English Exporters (London) Ltd,, [ro5s] 2 Lloyd's Rep. 69, in which MeNair, J., criticized D'Almeida Aruajo Ltd. v. Sir. Frederick Becker Ltd., [I953] 2 Q. B. 329.

${ }^{10}$ Macleod Ross \& Co. Ltd. v. Compagnie d'Assurances Generales L'Helvetia of St. Gall, [1952] I All E. R. 33 r.

${ }^{50}$ Another example in which the choice of the forum affected the relicf available was Scalcy v. Callan, [1953] P. I35, where a wife, whose husband was domiciled in Natal (South Africa), had acquired a residential qualification in England. When she intended to petition for divorce, she could elect between the residential forum in England and the domiciliary forum in Natal, a choice which, in view of the Matrimonial Causes Act, I950, $\$ 18(3)$, determined the substantive law of the divorce. Moreover, the South African court, unlike the English court, had no power to grant her maintenance, save by consent. She elected the English forum, although an English divorce was not recognized in Natal, and an application by the husband to the English court for a stay of proceedings until the South African court had decided on his counterpetition was dismissed by the English court. 
limitations and states that, from the comparative view, substantial agreement exists with respect to the following five: ${ }^{51}$

r. questions of procedure, which are universally governed by the lex loci;

2. questions of public policy;

3. in some cases, certain categories of standardized contracts governed by statutory provisions cannot be contracted out: ${ }^{52}$

Illustrations are contracts of incorporation, of insurance, of employment, sales on an exchange, contracts of payment, and other types of transactions. The systematic regulation of these important matters in an increasing number of jurisdictions deprives the parties pro tanto of an opportunity to specify the applicable law.

4. in many systems, questions of form and capacity; and

5. in many jurisdictions, ${ }^{53}$ a contract exclusively connected with a particular jurisdiction is necessarily governed by the law of that jurisdiction.

Of these restrictions, public policy requires special attention. ${ }^{\mathbf{5 4}}$ There is hardly a term to which various national systems attach more different meanings than to this one. Moreover, in some countries, limitations dictated by public policy are expressed in direct legal norms which are not ostensibly connected with public policy. Thus, in French law, the doctrine of interet national is an evolution of the principle of ordre public. ${ }^{55}$ In the Draft Code of French Private International Law, this doctrine is expressed as follows: ${ }^{56}$

An obligation contracted in France by an alien, incapable under the applicable foreign law but capable according to French law is valid, provided it has been undertaken towards a person who was unaware of the incapacity.

It is sometimes believed that in English law public policy is interpreted in a particularly narrow sense. While it is true that in matters of contract English law is still largely founded on the liberal principle of party autonomy, it should not be overlooked that the reluctance of English judges to resort to a broad principle of public policy is symptomatic of their reluctance to resort to any broad principle at all, and that many rules pertaining to public policy are, in English law, expressed in special rules ostensibly dealing only with particular problems. Thus, in municipal English law, the rule that the court will lean against an exemption clause ${ }^{57}$-i.e., a clause whereby a party attempts to exclude or restrict his common-law liabilityappears to be merely a rule of interpretation, namely, that such clause has to be

"1 Yntema, "Autonomy" in Choice of Law, I AM. J. Comrp. L. 341, 353-56 (I952).

E2 Id. at 353 .

${ }^{53}$ But not in England.

os See Kahn-Freund, Reflections on Public Policy in the English Conflict of Laws, 40 Transactions OP THE GRotTUS SOCIETY 39 (I954).

${ }^{25}$ See Delaume, A Codification of French Private International Law, 29 CAN. B. REv. 72I, 734-35 (195I).

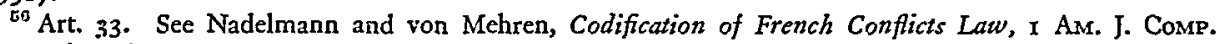
L. 404 (r952).

${ }^{67}$ Adler v. Dickson, [1955] I Q. B. 158. See also Olley v. Marlborough Court Ltd., [1949] I K. B. 532; Clive M. Schmitrhoff, The Sale of Goods 76 (I95I). 
interpreted narrowly, but is, in essence, a rule of public policy. In the conflict of laws, only two illustrations of this tendency of English law may be given. In British Nylon Spinners Led. v. Imperial Chemical Industries, ${ }^{68}$ the question arose whether a judgment by a United States District Court, in an action brought by the United States under the Sherman Antitrust Act ordering the defendant company (which was incorporated in England) to reconvey certain British patents to an American company, could affect those British patents. The plaintiffs, to whom the defendants had granted an exclusive license under the patents, asked for an injunction restraining the defendants from complying with the American judgment. The English Court of Appeal granted an interlocutory injunction, and later Danckwerts, J., ordered specific performance of the licensing agreement and continued the injunction until the exclusive licenses were registered in the appropriate registries. Evershed, M. R., said that, so far as the English patents were concerned, it was an assertion of extraterritorial jurisdiction for the American courts to make orders which would destroy or qualify those rights, a view clearly founded on the public policy of the lex fori. ${ }^{50}$ Denning, L. J., ${ }^{00}$ and later Danckwerts, J., ${ }^{01}$ however-and this is typical of the attitude of English judges when a problem of public policy arisesheld that the American judgment, owing to a savings clause, did not intend to conflict with English law. This apparent rule of interpretation is, it is submitted, indirectly founded on public policy.

Secondly, in Radio Corporation of America v. Rauland Corporation, ${ }^{02}$ a suit was pending in the United States between American corporations concerning an alleged infringement to violate the antitrust laws of the United States by a pooling arrangement of patents relating to electronics and by other means. Two corporations, which in the American proceedings were defendants, obtained in the United States letters rogatory for the examination of a large number of named witnesses by the United States Consul in London. All these witnesses were members of two English companies which were not parties to the American proceedings. The witnesses apparently did not voluntarily appear before the American Consul, and so the American corporations asked the English courts for an order under the Foreign Tribunals Evidence Act, $1856,{ }^{63}$ ordering their appearance and the production of the documents. This order was refused because the English courts would not have made such an order for discovery in English proceedings against third parties or, in the words of Lord Goddard, C. J., "it was a fishing procedure unknown to our courts."

${ }^{s 8}$ [1953] Ch. 19 (C. A.); [1955] Ch. 37 (Danckwerts, J.).

${ }^{80}[1953]$ Ch. at 26.

${ }^{\circ}$ Id. at 28.

${ }^{\text {ex }}$ [1955] Ch. at 54. Danckwerts, J., referring to a passage from the judgment of Judge Ryan in the United States District Court, said: "These passages indicate to me that his Honour Judge Ryan has been careful so to limit his judgment that neither his judgment nor any judgment of mine which the law of England requires me to give, will disturb the comity which the courts of the United States and the courts of England are so anxious and careful to observe."

[1956] 2 Weekly L. R. 612.

${ }^{83}$ I9 \& 20 VICT. c. II3. 
This ostensibly procedural rule was, again, substantially an application of English public policy.

To sum up, apart from the sphere of contract, in which the principle of autonomy is firmly upheld by the English courts, the concept of English public policy is, in fact, much wider than it is thought to be, only it is often disguised in specialized rules ostensibly unconnected with public policy.

\section{Conflict Avoidance and Evasion of Law}

In English law, which in the institution of the trust has developed an originally evasive device $^{64}$ to a legal concept of conscience, the distinction between avoidance and evasion of law is well known. The same is true of the civil-law countries, where the distinction has given rise to the doctrine of fraude a la loi. ${ }^{5}$ In French and German law, for example, avoidance is described as fraude licite or Umweg, and evasion as fraude prohibée or Schleichweg.

In municipal English law, as probably in many other municipal laws, the difference between avoidance and evasion is of particular importance in tax law. ${ }^{66}$ The legal and moral aspects of tax avoidance are considered in the following observations, the first by Lord Tomlin::

Every man is entitled if he can to order his affairs so as that the tax attaching under the appropriate Acts is less than it otherwise would be. If he succeeds in ordering them so as to secure this result then, however unappreciative the Commissioners of Inland Revenue or his fellow taxpayers may be of his ingenuity, he cannot be compelled to pay an increased tax.

\section{And by Lord Simon: ${ }^{68}$}

My Lords, of recent years much ingenuity has been expended in certain quarters in attempting to devise methods of disposition of income by which those who were prepared to adopt them might enjoy the benefits of residence in this country while receiving the equivalent of such income without sharing in the appropriate burden of British taxation. Judicial dicta may be cited which point out that however elaborate and artificial such methods may be, those who adopt them are "entitled" to do so. There is, of course, no doubt that they are within their legal rights but that is no reason why their efforts, or those of the professional gentlemen who assist them in the matter, should be regarded as a commendable exercise of ingenuity or as a discharge of the duties of good citizenship; on the contrary, one result of such methods, if they succeed, is, of course, to increase, pro tanto the load of tax on the shoulders of the great body of good citizens who do not desire, or do not know how, to adopt these manoeuvres.

Tax evasion, on the other hand, aims at avoiding the payment of tax, contrary to the law; such tax fraud renders a contract invalid and normally leads to criminal proceedings and the punishment of the offender. Tax avoidance is the habitual playing ground of the legal or accountancy practitioner. The neighboring field of

o' Sec Frederick W. Maitland, Equity 29 (I947).

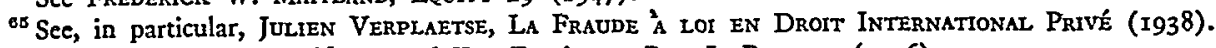

${ }^{60}$ See Bowman, Tax Avoidance and Tax Evasion, 3 Bus. L. REv. II (1956).

${ }^{\circ 7}$ Comm'rs of Inland Revenue v. Duke of Westminster, [1936] A. C. $x, 19-20$.

${ }^{88}$ Latilla v. Inland Revenue Comm'rs, [1943] A. C. 377,381 . 
$\operatorname{tax}$ evasion is taboo to these professional gentlemen, and an excursion into this forbidden land would have serious professional consequences for them.

It has been said ${ }^{69}$ that an evasive legal device has two elements:

x. an objective one, namely, the existence of a prohibitive legal norm of compulsory character-i.e., a norm which it is prohibited to infringe or abrogate; and

2. a subjective one, namely, evasive intention.

In the common law, however, which has not developed a general theory of evasion like that of fraude $d$ la lo $i$ in the civil law, the subjective element is not a sine qua non of evasion. Mr. Bowman observes ${ }^{70}$ that evasion of United Kingdom income tax can be committed innocently, and Professor Latty, when defining the evasive device of the "pseudo-corporation," expressly rejects the subjective test. ${ }^{71}$ Exceptionally, a particular legal norm in a common-law jurisdiction may adopt the test of intention as an additional requirement; this is, for example, the case in the English conflict relating to contracts, as will be explained presently.

Turning from these general observations to the distinction between avoidance and evasion in the conflict of laws, it should be noted, as Dr. Verplaetse points out, ${ }^{72}$ that the use of these devices in this subject does not correspond with their use in the general law because in the conflict, strictly speaking, there is no difference between these two devices: what is evasion in one legal system is avoidance in the other. Theoretically speaking, this ingenious reasoning is correct. It is, indeed, the characteristic of an evasive device in the conflict of laws that it is valid in one legal system but not in another. Thus, if the wife of a man domiciled in the Irish Republic acquires a residential qualification in England for the declared purpose of obtaining a divorce which she cannot obtain in Ireland, her divorce will be valid in England-and, under the rule in Travers $v$. Holley, possibly in some other countries-but it will be invalid in Ireland, ${ }^{73}$ and probably in many more countries. From the practical point of view of planning a conflict-avoidance device, however, this reasoning has to be rejected. Dr. Verplaetse himself states ${ }^{74}$ that the objective element of evasion in the conflict of laws, is always a legal norm of the lex fori. A practitioner who has to plan a transaction having a foreign complexion has to fix his eyes on the laws of the countries in which the transaction is most likely to be carried out; those laws are the presumptive leges fori, and he will have to take good care lest the proposed conflict-avoidance device infringes a compulsory prohibitive norm of those leges; otherwise, his device will be ultimately regarded as evasive and not as avoiding.

\footnotetext{
${ }^{60}$ Goldschmidt, The Evasion of Law in Spanish Private International Law, I Revuz HeLLENiguE DE Droit International 5 (1950).

${ }^{70}$ Bowman, stupra note 66 , at 14 .

${ }^{71}$ Latty, Psetudo-Foreign Corporations, 65 YALE L. J. 137 (1955).

is VeRplateTs, op. cit. sitpra note 65 , at 226.

${ }^{73}$ The law of the Republic of Irelanil does not admit a divore.

i Verplaetse, op. cit. sipra note 65, at 221.
} 
Two illustrations may be added, one taken from English and the other from American law.

It has already been mentioned that in international contracts, English law adopts the principle of party autonomy, which is interpreted very widely. It was held in the Vita Food case ${ }^{75}$ that the discretion of the parties to elect the proper law of contract was qualified by two limitations: their choice must be

I. bona fide and legal, and

2. must not contravene the public policy of the lex fori (in that case, English law). The first of these limitations is of interest in the present connection. Although it has not yet been defined by judicial authority, it is widely thought that it excludes a choice of law which is purely evasive. ${ }^{76}$ It is interesting to note that it adopts both the objective ("legal") and the subjective ("bona fide") tests, although, as has already been observed, a general doctrine of fraude a la loi is unknown in English law. Dicey observes: ${ }^{77}$

The requirement that the selection must be "bona fide and legal" raises more difficult issues. English courts have not in the past developed a doctrine of law evasion in connection with the conflict of laws. Nevertheless, no one can maintain that persons who really contract under one law, by pretending that they are contracting under another law, render valid an agreement which that law treats as void or voidable. If it is clear that if they meant to contract with reference to one law, e.g., the law of Scotland, no declaration of intention to contract under another law, e.g., the law of England, so as to give validity to the contract, will avail them anything. This result follows because in the view of the court their real intention was to enter into a Scottish contract and the court must determine its validity with reference to the law under which the parties really intended to contract.

In the United States, the problem of law evasion has recently been examined by Professor Latty with respect to the pseudo-foreign corporation. ${ }^{78}$ It is well known that in the United States no federal corporation law exists and that corporations are incorporated under the laws of the states or territories. These laws differ in their requirements: some are strict and contain detailed provisions aiming at the protection of creditors and minority. shareholders; others are lenient in their compulsory provisions. It has apparently become the practice in the United States for persons wishing to operate a corporation in state $A$ but desirous of evading particular aspects of its corporation law, to form their corporation under the law of state $B$ and to operate it in the territory of state $A$ as a "foreign" or, as Professor Latty calls it, a "quasiforeign" corporation. According to the learned author, the prototype of the pseudoforeign corporation can well be "the local hotel owned entirely by local residents but incorporated out of state-say in Delaware."79 Professor Latty distinguishes the quasi-foreign corporation from real foreign corporations, the cosmopolite, the rootless,

${ }^{75}$ Vita Food Products Inc. v. Unus Shipping Co., [1939] A. C. 277, 290 (P. C.).

${ }^{70}$ See Albert V. Dicey, Conflict of Laws 586 (6th ed. 1949); R. H. Graveson, Conflict of Laws I94 (3d ed. 1955); Schmimthoff, op. cit. supra note 8, at 114, 115-16 (3d ed. 1954).

${ }^{77}$ DiceY, op. cit. supra note 76 , at 586-87.

${ }^{78}$ Latty, supra note $7 \mathrm{I}$.

${ }^{70}$ Id. at 137. 
and companies having substantial managerial or other business interests in several jurisdictions. As he points out, the device of quasi-foreign corporations is likewise known in Europe: in the second half of the nineteenth century, England was apparently the Delaware for French enterprise seeking to evade the rigorous French corporation law, and in one litigated case, an attempt was even made to anglicize Moulin Rouge by forming the "Moulin Rouge Attractions Ltd."80

There is no doubt that the device of quasi-foreign corporateness is a device of law evasion. It is not easy to determine the quasi-foreign status of a corporation unless it is an "out and out local enterprise, locally operating, locally managed, and locally financed." ${ }^{21}$ Professor Latty suggests, for the determination of that status, objective tests and points out that a foreign corporation may be quasi-foreign with respect to some protective local laws but not with respect to others; speaking generally, he would adopt the test of predominance of local interests. He says: ${ }^{82}$

Given the predominantly local situs of the business, the ad hoc status of the corporation as pseudo-foreign should be determined by the predominance of the local interests among those to be protected. To illustrate: if most of the shareholders (or maybe even most of the minority shareholders outside the management group) are local residents, the local requirement for cumulative voting might be applied at the request of the local shareholders. Again, if one class of shares is held predominantly by local residents, the requirement of voting by classes on fundamental changes in the charter might govern. All of which amounts to saying that for this purpose, the localized foreign corporation is pseudo-foreign. On the other hand, if local interests do not predominate, they might well be left to take their chances, along with the predominantly foreign members of their class, with the provisions of the law of the state of incorporation; and in such a case the corporation will not be considered pseudo-foreign.

Professor Latty advances the persuasive thesis that "no fundamental principle of conflict of laws requires the forum to apply only the law of the state of incorporation to a pseudo-foreign corporation, even in matters relating to internal affairs," and suggests a selective application of local corporation law "where there are protective features in local law reflecting a strong public policy."83 The essence of his case against the quasi-foreign corporation is that as that device is clearly in fraudem legis, it should be treated, where the local corporation law makes this necessary, as an evasive device and not as a means of conflict avoidance.

It is obvious from these observations that the area and effect of evasion vary in different jurisdictions. A practitioner, intent to introduce a device of conflict avoidance into a transaction having a foreign complexion, will, therefore, have to examine not only the different meaning and extent of party autonomy in various countries, but likewise the question whether the device which he proposes to adopt would be considered as evasive in those jurisdictions.

${ }^{30} \mathrm{Id}$. at 166 n. 130.

${ }^{81} I d$. at $16 \mathrm{x}$.

${ }^{83}$ Ibid.

${ }^{83} I d$. at 172 . 
D. Conflict Avoidance in the Wider Setting of Selective Law

In the planning of a complex international transaction, conflict avoidance is only one of the determining elements and not always the most important one.

Other facts which have to be analyzed are: the incidence of taxation in the various countries; the peculiarities of local corporation laws, in particular, whether they require a certain proportion of the directors or shareholders to be nationals or residents of the countries to which they apply; labor and industrial legislation; patent and trade-mark laws; and exchange-control and other government regulations. Other legal matters which have to be taken into account are the general standard of justice in the countries in question; access to the courts by foreigners; legal expenses and recovery of costs of litigation; and so forth. Further, general background trends must nót be neglected, such as economic, financial, and political factors.

It would be beyond the compass of this paper to analyze the elements of law selection beyond those pertaining to conflict avoidance. It may, however, be added that a general knowledge of the laws in their functional state and of the constantly changing background tendencies in various countries is required of the legal planner of an international transaction. To him, in his specialized field of work, comparative law is not a subject of academic predilection, but it forms part of his tools of trade.

\section{II}

\section{The Localization of International Transactions}

In this part, it is intended to examine the practice of conflict avoidance on the private level.

\section{A. General Considerations}

In his article on Conflict Avoidance in European Law, Professor Batiffol, when discussing the various devices of conflict avoidance on the international level, refers to a duality of ways in which unification of laws may be achieved $:^{84}$ a convention may either aim at a complete and general unification of the law in a particular field, or it may have the less ambitious aim of laying down rules for the avoidance of a conflict of laws in a particular situation. A good example of the former is the Brussels Convention of 1924 , recommending for international adoption the Hague Rules of I92I on Bills of Lading; an illustration of the latter is the Draft Convention on the Conflict between the Laws of Nationality and Domicile (Renvoi) accepted by the Seventh Session of the Hague Conference on Private International Law in I95I.

It is believed that the distinction drawn by Professor Batiffol between total and partial tendencies of conflict avoidance applies not only on the international level, but likewise on the private level. In some cases, the localization device is employed to subject the transaction so clearly and firmly to a particular local law that problems pertaining to the conflict of laws are practically excluded. In other cases, the

st Batiffol, Conflict Avoidance in European Law, infra 575-80. 
existence of a conflict of laws is accepted, but a device-and a device properly pertaining to the conflict of laws-electing the proper law of the transaction is employed. A total localization device is, for example, the confirmed banker's credit, which localizes the payment of the price under an international contract of sale in the country of the seller; a partial localization device is, for example, a choice-of-law clause, by which the parties agree on the proper law of their contract.

\section{B. Total Localization Devices}

Two typical total localization devices are the confirmation of a commercial obligation by a local bank or a local agent, and the local subsidiary of a foreign controlling company.

\section{The Confirmation in Commercial Transactions.}

The device of confirmation is used extensively in modern export trade law, in which it appears in two forms:

a. as confirmed commercial credit, and

b. as undertaking of a confirming house.

a. Confirmed Commercial Credits. When an exporter residing in $X$ sells goods to an importer residing in $Y$, the parties may agree that payment of the price is to be made at the locality of the seller, namely, in $X$, under a confirmed commercial credit to be opened with a bank in $X$, subject to certain conditions, in particular, the delivery of certain documents, including normally, but not necessarily, ${ }^{85}$ the bill of lading evidencing shipment of the goods within the stipulated time.

Where there is a "string" or "chain" of contracts of sale-e.g., $A$ buying from $B, B$ from $C, C$ from $D$, and so forth-the ultimate buyer's commercial credit may become the guiding finance for the whole chain, either by making his credit transferable and divisible or by using it as the financial foundation for the whole complex transaction which may extend over many countries according to the place of residence or business of the various parties in the chain of contracts. This was, for example, the case in Sinason-Teicher Inter-American Grain Corporation v. Oilcakes and Oilseeds Trading Co., ${ }^{86}$ which concerned a "switch-transaction" between parties in the United States, United Kingdom, and Germany; "Baltimex" Ltd.v. Metallo Chemical Refining Co., in which the transaction extended to Belgium, West Germany, England, and Russia; and Trans-Trust S. P. R. L.v. Danubian Trading $\mathrm{Co}_{0}{ }^{88}$ where the suppliers were Belgian, the intermediaries English, and the ultimate buyers American.

It is not proposed to explain here the legal aspect of the confirmed commercial credit as a device of international finance. ${ }^{89}$ It is merely intended to draw attention

\footnotetext{
${ }^{85}$ Not in the case of so-called packing credits. See Clive M. Schmitriorf, The Expont Trape 194 (3d ed. 1955$)$.

${ }^{80}$ [1954] I Weekly L. R. 935, 1394 .

87 [1955] 2 Lloyd's Rep. 438.

$88[x 952] 2$ Q. B. 297 (C. A.).

${ }^{80}$ Sec SchMirthoff, op. cit. supra note 85 , at 182.
} 
to the purpose and function of a confirmed banker's credit in modern commerce, which is to add the bank's own obligation to that of the buyer. The bank undertakes, in short, unequivocally and unconditionally to pay the sum to the seller if the conditions laid down in the advice are satisfied. It has been held that this obligation of the bank is not affected by any revocation of the mandate to the bank by the buyer ${ }^{90}$ Some thirty years ago, when commercial credits-which came into use after the First World War-were relatively new, two qualities of these credits-i.e., their irrevocability and the confirmation-were sometimes confused. In modern law, this controversy has long been settled, and it is now generally assumed that while the revocability of the credit refers to the power of the buyer as customer of the bank, confirmation refers to the independent undertaking by the bank to pay the seller. ${ }^{12}$ While normally the bank, when asked to confirm, will insist on the buyer making the credit irrevocable, conversely, in practice, irrevocable and unconfirmed credits are met occasionally.

The purpose of confirmation by the bank is to localize payment of the price under a contract of export sale in the seller's country. For that reason, the English courts have constantly said that the arrangement of a confirmed credit in a contract of sale is stipulated for the seller's, and not the buyer's, benefit, and have interpreted the terms of the credit accordingly. ${ }^{92}$ In the confirmation by banks, modern commercial practice has evolved a device which operates very efficiently as a means of conflict avoidance: issues involving commercial credits have been before the courts increasingly frequently, but, at least as far as the United Kingdom is concerned, such litigation has so far never raised a question pertaining to the conflict of laws. The two principal works on commercial credits in England, Professor A. G. Davis' The Law Relating to Commercial Letters of Credit (2d ed. 1954), and GutteridgeMegrah's The Law of Bankers' Commercial Credits (2d ed. 1955), reflect this position: the former does not contain a reference to the conflict of laws at all, and the latter, though treating it in a separate chapter ${ }^{93}$ does not refer to any English cases in which conflict-of-laws problems relating to commercial credits were discussed.

In view of the international character of the commercial credit and the modern tendency of using it as a means not merely of bilateral, but likewise of multilateral international sales finance, the high efficiency of confirmation as a conflict-avoidance device is remarkable; the more so as it does not deprive the transaction of its international character-that would be impossible-but merely removes the international factor from the contract of sale to that of banking.

It is further interesting to note that this conflict-avoidance device is not founded

${ }^{20}$ Urquhart Lindsay v. Eastern Bank, [1922] I K. B. 318 . This is also the American practice. See McGowan, Assignability of Doctumentary Credits, 15 Law \& Contemp. Prob. 668 (I948).

"Only International Chamber of Commerce, Uniform Customs and Practice for Comamercial

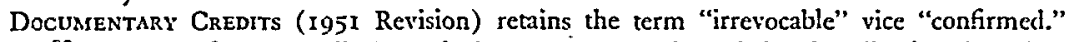

${ }^{92}$ E.g., "Confirmed credit is a devise, as I see it, intended primarily for the seller's benefit." Per MeNair, J., in Pavia \& Co. v. Thurmann Nielsen, [195I] 2 All E. R. 866, 868, aff'd, [1952] I All E.R. 492 (C. A.).

${ }^{03}$ C. 9 . 
on the idea of uniformity, although a considerable degree of uniformity has facilitated its practical use. The International Chamber of Commerce has issued two important publications, namely, Uniform Customs and Practice for Commercial Documentary Credits ${ }^{34}$ and Standard Forms for the Opening of Documentary Credits. ${ }^{95}$ Neither of these sets of rules has been adopted by banks in the United Kingdom, which fear that the adoption of standard rules may arrest the natural evolution of commercial credits; but in the United States, France, Germany, and many other countries, bankers' associations or individual banks adhere to the Uniform Customs and sometimes likewise to the Standard Forms. ${ }^{90}$ That the reason for the success of the confirmed credit as a means of conflict avoidance is not the element of unification, but that of localization of the payment of the price in a particular country, is evinced by the fact that even in the United Kingdom, no conflict problems are raised by the use of that device.

b. Confirmation by Confirming Houses. This device is used, for example, in the following circumstances: A manufacturer of textiles in England has an agent or representative in Australia who obtains an order from an Australian wholesaler or retailer. The English manufacturer accepts, "subject to confirmation by an English confirming house," often naming a particular business, say, $X$, which will then place an order with the manufacturer for the same goods which the Australian importer ordered. X's "confirmation" will be in one of the following forms: either it will place this order in its own name, making itself vis à vis the English manufacturer, the buyer of the goods; or it will make itself independently responsible in addition to the overseas principal. An advice by the confirming house, which often calls itself "export and import agents," that they "confirm" merely as agents on behalf of the overseas principal is possible, but would probably be rejected by the manufacturer as being insufficient and contrary to the agreement with the Australian importers, since the effect of it would be to render the overseas principal solely liable, and this would defeat the principal purpose of the device, which, like the confirmation of the banker, is to localize the transaction in the seller's country. ${ }^{97}$

The effect of the confirmation, as far as the overseas importer and the municipal manufacturer or wholesaler is concerned, is that the sales transaction ceases to be an international transaction and is turned into a home transaction incapable of raising a conflict issue.

The confirmation issued by a confirmation house has been considered in two recent cases, Rusholme \& Bolton \& Roberts Hadfield Ltd. v. S. G. Read \& Co. ${ }^{98}$ and Sobell Industries Ltd. v. Cory Bros. \& $\mathrm{Co}^{99}$ In both cases, the court held the

\footnotetext{
ol International Chamber of Commerce, op. cit. silpra note i 7 .

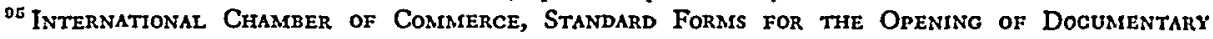
Credits (I95I).

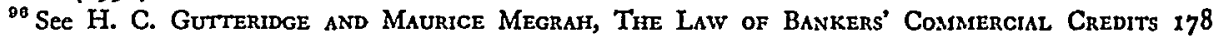
(2d ed. I955); Fernand Lison, A propos de Credits Documentairer 5 (1956).

${ }^{97}$ On confirmation by a confirming house, see Schmirthoff, op. cit. stipra note 85 , at 129 et seq.

${ }^{88}$ [1955] r Weekly L. R. 146.

${ }^{\circ 9}$ [1955] 2 Lloyd's Rep. 82.
} 
confirming house to be liable on its undertaking. In the second case, McNair, J., observed: $:^{100}$

The critical question is: What is the meaning of "confirming order" or what is the meaning of "confirming house"? . . . It seems to me, using the word in its ordinary sense, "to confirm" means that the party confirming guarantees that the order will be carried out by the purchaser. In that sense he adds confirmation or assurance to the bargain which has been made by the primary contractor, just as a bank which confirms that a credit has been opened by the buyers in favour of the seller guarantees that payment will be made against that credit if the proper documents are tendered.

These forms of confirmation would be valueless, or would at any rate lose much of their value, if the assurance given in the one case that the contract would be performed, and, in the other case, that the credit would be available when the documents were presented, that payment would be made against it, could be withdrawn by the confirming party on the instructions of the person for whom he has given the confirmation....

In the case of a confirmation given by a confirming house, it is the contract as a whole that is confirmed and it seems to me that the whole purpose of the arrangement ... is that the seller shall have a responsible person in this country to perform the contract as a whole.

It may be worthwhile to consider the difficulty which the sellers in those two cases escaped by adopting the conflict-avoidance device of confirmation by a confirming house. In the Rusholme case, owing to a trade recession before the delivery date, the Australian importers cancelled their order, and later the Australian Government imposed import restrictions. In the Sobell case, the overseas buyers were Turkish importers who had withdrawn their instructions to the British confirming house, Cory Brothers, to accept the goods. In both cases, the sellers, had they not insisted on localization of the contract in their own country, would have found themselves involved in difficult litigation, and even if they could have sued in their own country under the assumed jurisdiction of the courts, the enforcement of the judgments would have been subject to the uncertainty inherent to enforcement abroad. From the practical point of view, the adoption of the localization device of confirmation meant to them just the difference between obtaining satisfaction and, to put it at the lowest, being procrastinated.

c. Comparison of Confirmation Devices. When comparing the two types of confirmation-namely, that issued by a bank under a commercial credit and that issued by a confirming house-it is obvious that the former has merits of safety, but the latter has merits of extent. The bank confirms merely one aspect of the export sale-namely, the buyer's obligation to pay. If this device is used in a c.i.f. contract (under which the risk passes to the buyer on shipment), it may give the seller fairly full protection; but that protection may be illusory under a contract which is not a true c.i.f. contract, because if such a contract is frustrated and there is total failure of consideration, the seller may have to refund the price which the buyer paid in advance, ${ }^{101}$ even though payment was made by a bank under a confirmed credit.

${ }^{100}$ Id. at 89 .

${ }^{101}$ See Comptoir d'Achat v. Luis de Ridder; The Julia, [1949] A. C. 293. 
On the other hand, the confirmation by a confirming house localizes the contract in its entirety in the country of the seller, and frustration occurring in the importer's country is completely irrelevant from the point of view of the seller, although, of course, it might affect the relation between the overseas importer and the confirming house-a relation normally founded on the contract of agency.

\section{The Foreign Subsidiary.}

Although it is well known that the foreign subsidiary is a widely used device in international corporate business, it is difficult to illustrate the practical application of the device by actual examples. This stems from two causes: corporations having interlocking devices of international character are often somewhat chary of disclosing their extent and operation to the public; and the municipal corporation laws do not usually compel them to do so. Thus, the Companies Act, $1948,{ }^{102}$ one of the strictest corporation laws in operation at present, while providing ${ }^{103}$ that, on principle, ${ }^{104}$ a holding company, as the parent company is called by the act, shall present group accounts consisting of a consolidated balance sheet and profit and loss account of the company and its subsidiaries and sub-subsidiaries, including the foreign ones, it does not oblige a holding company to give a list of its subsidiaries, nor does it enjoin it to disclose the extent of its holding in them. A consolidated balance sheet stating that it" is the balance sheet of the "X.Y.Z. Co. Ltd. and roo Subsidiaries," or simply that it is the balance sheet of "X.Y.Z. Co. Ltd. and Subsidiaries," satisfies the requirements of the act. One has to turn to unusual sources of information in order to gain an idea of the extensive use of the foreign subsidiary as a constructional device in the organization of the international economic empires of our time. The following data are taken from the London Stock Exchange 'Official Year Book, I955:

Ford Motor Company Limited (A subsidiary of Ford Motor Co. of Dearborn, Michigan).$^{105}$

Esso Petroleum Company Limited (A subsidiary of Standard Oil Co. (New Jersey)). ${ }^{106}$

Imperial Chemical Industries Limited

Company also has the following subsidiaries (inter alia):

(a) Overseas-

Arnold, Hoffmann \& Co., Inc.; Azamon S. A.; Canadian Industries (1954) Ltd.;

103 Ix \& 12 Geo. 6 , c. 38.

${ }^{103} 1 d$. $\S 15 \mathrm{x}(\mathrm{I})$. For definition of holding company and subsidiary company, sec id. $\$ 154$.

${ }^{104}$ This principle is subject to a number of exceptions:

(r) No group accounts are required if the company is the wholly-owned subsidiary of another British company because in that case, its holding company has to provide group accounts $(\S 150(2)(a)) ;$

(2) group accounts may be presented in another form than consolidated accounts if the lattcr are not readily appreciable by the shareholders $(\$ 15 \mathrm{I}(2))$; and

(3) in a few other exceptional cases, they may be dispensed with, normally by consent of the Board of Trade (\$150(2)).

${ }^{100} 2$ London Stock Exchange Official Year-Book 2225 (1955).

${ }^{100} \mathrm{x}$ id. at II73. 
"Duperial" companies in Argentina and Urugauy; Khewra Soda Co. Ltd. and Imperial Chemical Industries companies in Australia, Belgium, Brazil, Canada, Chile, Egypt, France, Holland, India, Israel, Japan, Malaya, New York, Pakistan, Peru, South Africa, Sudan, and Turkey, and through its Indian company has a controlling interest in Alkali \& Chemical Corporation of India Ltd. and through its South African company has a controlling interest, jointly with De Beers Industrial Corporation Ltd. . . . in African Explosives and Industries Ltd., and

(b) in the United Kingdom

[here follow the names of 15 companies]. ${ }^{107}$

\section{British Petroleum Company Limited}

[This company is listed under its former name of Anglo-Iranian Oil Co. Ltd.] More than $3^{0}$ subsidiaries are listed, many of which are foreign.

It is interesting to note the different use made of the initials " $\mathrm{B}$. P." In the United Kingdom and many parts of the British Commonwealth these letters are understood to denote "British Petroleum," e.g., B. P. (India) Ltd.; in other countries they appear to mean "Benzine and Petroleum," e.g., Benzine and Petroleum A. G. (Austria), or Benzine en Petroleum Handel Maatschappij N. V. Only in Italy the name of the subsidiary is "Britannica Petroli S. P. A."] 108

The typical feature of the foreign subsidiary is that it is incorporated in the country of its operation and in that country, at least in principle, is regarded as a municipal corporation. This device enables an enterprise to carry out the seemingly impossible feat of sitting on both sides of the fence at the same time, by being a local corporation in form, but a foreign enterprise in substance.

The device of local incorporation does not, of course, operate in all circumstances. In some legal relations, the legislature has "pierced the veil" and adopted other tests than that of incorporation. Thus, in English law, as has already been observed, the group accounts required on principle of holding companies have to include foreign subsidiaries or sub-subsidiaries. Further, United Kingdom exchange-control and tax law applies in certain circumstances to overseas subsidiaries of United Kingdom parent companies. ${ }^{109}$ A typical application of the test of control as the test overriding that of nationality occurs in the law relating to enemies: The British Trading with the Enemy Act, I939, section 2(I) (c), states that an "enemy" within the meaning of the Act is: ${ }^{110}$

... any body of persons (whether corporate or unincorporate) carrying on business in any place, if and so long as the body is controlled by any person who, under this section is an enemy. ...

At common law, the test of alien enemyship of a corporation is likewise the test of control. ${ }^{111}$

Whenever it is intended to use the foreign subsidiary as a conflict-avoidance

1072 id. at 2438.

${ }^{100} \mathrm{I}$ id. at $1 \mathrm{I}^{6} 4$.

100 See SchmitrmofF, op. cit. supra note 85 , at 146 et seq.

$1102 \& 3$ GEo. 6, c. 89 .

${ }^{212}$ See Daimler Co. Ltd. v. Continental Tyre and Rubber Ltd., [rgr6] 2 A.C. 307; Kuenigl v. Donnersmark, [1955] 2 Weekly L. R. 82. 
device, two fundamental problems arise: in what respects is the independent status of that device recognized, or, vice versa, in what respects is it disregarded by the law of incorporation of the countries

a. of the parent corporation, and

b. of the subsidiary.

As regards the law of incorporation of the subsidiary, many factors have to be taken into account. ${ }^{112}$ There is first the corporation law factor. The corporation laws of some countries-e.g., the Scandinavian countries and Switzerland-postulate residential or national qualifications for directors or shareholders. These requirements, however, can often be overcome by the use of "dummies." In some countries-e.g., U.S.S.R., Turkey, Argentina, Bolivia, Guatemala, Haiti, Honduras, and Uruguay-incorporation depends on the grant of a government license, which may be refused on the ground of administrative expediency and discretion. In some countries, particularly in Latin America, a factor of labor law enters into the picture: the company must have on its payroll a number of nationals of the country in question. If the foreign subsidiary is intended to have a joint management, questions of local aliens law may arise; and some countries-e.g., the Union of South Africa-have a nonresident shareholders' tax. It follows that considerable research is necessary before a foreign subsidiary can be set up and that that form of international business organization is not appropriate in all circumstances. Apart from these cases, however, the use of a foreign subsidiary is, in practice, very common, and it is significant that in October I954, the British Board of Trade published a pamphlet entitled Setting up a Subsidiary in Canada, in which it advises British exporters how to set about to incorporate subsidiaries in that country. One of the points dealt with in the pamphlet is a short reference to the problem whether such subsidiary should be incorporated under federal or provincial laws.

When the foreign subsidiary can be employed, it is undoubtedly a total conflictavoidance device of highly effective nature. Apart from the cases in which the local law "pierces the veil," the foreign subsidiary is treated as a municipal, and not a foreign, corporation in the country of its operation. Its whole life and activities are, apart from these exceptional cases, removed from the sphere of the conflict of laws: the contracts which it enters with third parties in that country do not contain a foreign element, but are "home" transactions; and the contracts which it concludes with its parent corporation, although retaining international character, will not give rise to conflict problems, since they are hardly more than interdepartmental differences capable, if need be, of settlement by managerial authority. In addition, some potential conflict disputes are removed into the sphere of internal corporation lawe.g., disputes between the controlling interest and local minority shareholders.

In view of the effectiveness of the device of the foreign subsidiary as a means of conflict avoidance, it is not only employed where a corporation wishes to build up an

${ }^{112}$ See Schurtrhoff, op. cit. stpra note 85 , at 151 et seq., on which the details in the text are founded. 
international business organization, but it is likewise used in ordinary export transactions. One example may suffice here: an importer in country $A$ negotiates with a manufacturer in country $B$ for the exclusive representation of the manufacturer's goods in $A$. A sales tax is in operation in $A$, according to which tax is payable on every turnover of the goods. The importer, therefore, suggests to the exporter that instead of selling the goods to him for resale to a wholesaler who then subsells to a retailer who deals with the ultimate consumer, the importer will name the ultimate retailer to the manufacturer who will then sell to the consumer directly, the price excess to be handed over to the importer. The manufacturer will rightly refuse to enter into this transaction, which might involve him in very difficult questions arising under the law of $A$, and he will suggest to the importer that the latter should form his own subsidiary in $B$, to whom the manufacturer will sell the goods, leaving it entirely to the importer, through his subsidiary, to deal with the difficulties of the market in $A$. By the use of a subsidiary in $B$, the export transaction is localized in $B$, and no conflict-of-laws questions or other problems of international character can arise between the manufacturer and the importer.

\section{Adoption of Autonomous International Regulations.}

A new method of conflict avoidance is attempted in the case of some international corporations. By the international conventions under which they are created, they are given an autonomous statute containing such detailed regulation of their organization, management, and conduct of affairs that-this, at least, is the intention of their creators-it will be unnecessary to resort to any municipal system of law if they are involved in a legal dispute. The aim of this method of conflict avoidance is different from the normal aim of avoidance devices on the private level. The object here is not to localize a transaction in a particular country and thereby to remove it from the field of conflict of laws to that of municipal law, but, on the contrary, to avoid conflicts by transferring the transaction in question to the international level and to make it, so to speak, self-supporting there.

Professor Batiffol gives two illustrations of this method of conflict avoidance: $:^{113}$ the proposed European corporation which is intended to be governed by its own law, although, as a precautionary measure, in every convention creating such corporation, reference will be made to a named municipal law in case of need; and the Bank of International Settlement, where, as Professor Batiffol observes, the position is obscured, because, although it was intended that the corporation should exist on the authority of its own statute, the convention creating it provided that legal character should be conferred upon the bank by Swiss law.

It has been suggested that an International Corporation Register should be created and kept by a noncontentious Division of the International Court of Justice at The Hague. ${ }^{114}$ This Register should ${ }^{115}$

\footnotetext{
${ }^{113}$ Batiffol, Conflict Avoidance in European Law, infra 571, 575-78.

114 See Schmitthof, supra note 9.

${ }^{210} \mathrm{Id}$. at $18 \mathrm{I}$.
} 
... be open both to corporations created by international agreement and . . national corporations the constitution of which is protected by international convention. ... A A special division of the Register would be reserved for the voluntary registration of International Cartels.

\section{Limitations of Total Localization.}

The reader will have observed that when the normal devices of total localization were discussed, it was pointed out that their use did not remove, but merely shifted, the international element of the transaction.

In the case of the confirmation device, the international factor is removed from the seller-buyer relationship, under a banker's credit, to the relationship between banks or a bank and its customer, and where a confirming house is used, to that between principal and agent. In the case of a foreign subsidiary, the international element is, to a large extent, transferred to the interdepartmental atmosphere of parent and subsidiary corporation or to the arena of a municipal system of corporation law.

These qualifications indicate the limits of localization: even a total localization device cannot abolish or eradicate the international character of a transaction, but can only transfer it from a highly vulnerable area of conflict of interest to a less vulnerable one in which such a conflict is less likely to occur. Such transfer is, indeed, the purpose of a total localization device; it is conflict avoidance in a practical sense.

One of the most vulnerable spheres is the seller-buyer relationship. The informal character of many international sales agreements, the fluctuation of markets, a lack of permanency in the relationship of the parties, and similar factors create an atmosphere in which misunderstandings can easily arise and eventually lead to litigation which might necessitate the solution of issues pertaining to the conflict of laws. The confirmation device aims at transferring the international element from that susceptible relationship to more robust relationships-more robust, perhaps, because they contain a higher element of mutual confidence and of good faith.

\section{Partial Localization Devices}

\section{The Direct Choice-of-Law Clause.}

The great partial localization device is the choice-of-law clause-i.e., a clause by which the parties submit the contract or other relationship of autonomous character to the law of a particular country. The general aspects of this subject have been fully explored, ${ }^{116}$ and the interesting problems of the choice of law relating to special business transactions are treated in other articles of this symposium.

The purpose of a choice-of-law clause is this: The parties envisage-or at least do not rule out-the possibility of a conflict of laws and make arrangements for that contingency by providing that the proper law of their contract shall be the law of a

\footnotetext{
${ }^{110}$ See, e.g., G. C. Cheshire, International Contracts (1948); Gravcson, The Proper Latw of Commercial Contracts in the English Legal System, in Conflict of Laws and Internationat. ConTRACTS I (r949).
} 
particular country. Such partial localization device is only an imperfect means of localization, and this for two reasons: First, it does not prevent the conflict issue from arising in various jurisdictions; it only lays down that, irrespective of whether the dispute arises in countries $A, B$, or $C$, it shall always be the law of, say, $B$ which shall govern the transaction. Secondly, the court of the country in which the dispute is actually litigated may interpret the proper law of contract which the parties have chosen differently from the courts of other countries with which the transaction is connected. Thus, in our example, the courts of $A$ or $C$, when attempting to ascertain the law of $B$, may erroneously, but, as far as the parties are concerned, finally, find the law of $B$ to be different from that law as it would be interpreted in the courts of $B$, had the courts of $B$ been called upon to decide the issue.

In order to be truly effective, a choice-of-law clause should invariably be combined with a jurisdiction clause which provides that the courts of a particular country shall have exclusive jurisdiction to deal with the issue. If, in our example, the agreement of the parties that the law of $B$ shall govern their contract is supplemented by the further agreement that the courts of $B$ shall have sole jurisdiction to deal with any disputes between the parties, the vagaries of the pure choice-of-law clause are excluded. The combination of a choice-of-law clause with a jurisdiction clause is not, however, always possible, because the latter arrangement may offend against the public policy of the lex fori of some of the countries with which the transaction is connected and may, in that case, jeopardize the whole avoidance device.

\section{The indirect Choice-of-Law Clause.}

The typical indirect choice-of-law clause is the arbitration clause.

It is widely held, and rightly so, that if the parties agree on arbitration to be held at a particular locality, this imports a choice-of-law clause, namely, an agreement that the law of the arbitration tribunal shall be the proper law of the contract.

The essential point of such arbitration clause is the localization of the arbitration at a particular place. It has happened occasionally in international contracts that arbitration clauses were adopted without a localization device. For instance, English and Italian parties to a contract of sale may adopt an arbitration clause according to which, in case of dispute, each party shall appoint an arbitrator and, in case of dissent, both arbitrators shall elect an umpire. Such clause is worthless, even as a partial localization device. If, at the request of one party, the other fails to appoint an arbitrator, are the consequences to be treated according to English law or Italian law? This question can only be solved by first ascertaining the proper law of contract, so that in this case, the arbitration clause does not determine the proper law of contract, but the contrary is the case.

That, indeed, it is the localization aspect-namely, the provision that arbitration shall be held at a particular locality-which makes the arbitration clause a valuable avoidance device is clearly recognized in the arbitration clauses sponsored by the American Arbitration Association. An illustration is afforded by the so-called 
British-American Arbitration Clause which the London Court of Arbitration-the arbitration tribunal of the London Chamber of Commerce-recommends for insertion into contracts made between traders in the United Kingdom and the United States of America; that clause is worded as follows:

Any controversy or claim arising out of or relating to this contract or breach thereof shall be settled by arbitration. If the arbitration is held in England, it shall be conducted under the Rules of the London Court of Arbitration and the construction, validity, and performance of the contract shall be governed by the law of England. If the arbitration is held in the United States, it shall be conducted under the Rules of the American Arbitration Association. Judgment upon the award rendered may be entered in any court having jurisdiction thereof. In the event that the parties have not designated the locale of the arbitration and are unable to agree thereon, either party may apply to the International Law Association in London to decide the locale and its decision shall be accepted by the parties thereto.

It will be noted that this clause defines the locale of arbitration with great care and even goes to the length of having an arbitration on the question of the locale if the parties have failed to designate it or are unable to agree on it. The aim of this clause is to leave no loophole for the partial localization of the transaction and to assure that the arbitration clause will perform its function as a means of definition of the choice of law. The result of this regulation is, however, that if English law is in favor of one party and American law in favor of the other, the determination by the International Law Association in London of the locale of arbitration decides, in fact, the substantive issue between the parties. In such a case, the International Law Association assumes, from the practical point of view, the position of an umpire.

The possibility that the localization aspect of the arbitration clause might not perform its function of defining the proper law may likewise arise in an arbitration under the rules of the Court of Arbitration constituted by the International Chamber of Commerce. Here, the nationality and residence of the arbitrator are, as a rulc, different from that of the parties. Surely, in this case, neither the law of the place at which the arbitration is held nor French law, as the lex fori of the Court of Arbitration, can be the proper law of the contract. In such a case, if the question is relevant, it is thought that it would be the duty of the arbitrator to ascertain what the proper law of the contract is. No case of this kind has so far been reported in the English jurisdiction.

\section{III}

Conflict Avotdance and the Theoretrcal Bases of the Conflict of Laws

It is proposed in this part to indicate briefly the effect which the recognition of the topic of conflict avoidance as a corollary to that of conflict solution is likely to produce on the theory of the conflict of laws. 
A. The Theoretical Foundation of Conflict Avoidance

Since conflict avoidance is actively practiced on the international, national, and private levels, some measure of fundamental similarity of legal institutions must already be in existence in many parts of the world. The various legal systems with which an international transaction is connected may differ on points of detail-e.g., in the law of contract, on the extent to which party autonomy is admitted or to which public policy is applied; or in corporation law, on the requirements for the creation of a foreign subsidiary. Yet, some fundamental notions must be common to the legal systems with which the transaction is connected-e.g., the rule pacta sunt sevanda and the recognition of the legal persona of a corporation. The selective process characteristic of conflict avoidance on the private level could hardly be applied if there did not exist such similarity of fundamental legal ideas in many parts of the world; and the unifying attempts of conflict avoidance on the international level, which at least in the field of international commercial law have achieved some measure of success, would not be possible if the parties to an international agreement or the national bodies sponsoring an international practice did not only share a similarity of outlook as to the fundamentals of the legal institutions with which the agreement or practice is concerned, but, beyond that, were in substantial agreement on the detailed rules applicable to those institutions.

\section{B. The Local Rights and Vested Rights Theories}

The two great theories propounded as a basis of a conflict system by modern writers are the theories of local rights, founded on the writing of W. W. Cook, and the theory of vested rights, adopted, in a modified form, by the authors of the sixth edition of Dicey and others. It is the merit of Professor Lederman, in his Conflict Avoidance by International Agreement, ${ }^{117}$ after giving a brief exposition of these two theories, to have examined their relationship to conflict avoidance on the international level. When referring to the vested right theory, the learned author states that this theory ${ }^{118}$

... necessarily presumes that there are universal and uniform tests valid for all national legal systems whereby this task of definition and allocation can be implemented.

This analysis is, it is believed, in substance correct. While the vested rights theory rejects the narrow nationalism of the local rights theory, which fails to explain why a national law should take notice of foreign law at all, and equally rejects the unreal thesis of supranational law, it recognizes the existence of fundamental similarity of legal concepts in many parts of the world without denying that the source of application of a conflict norm in a municipal jurisdiction is the power of the sovereign in whom that jurisdiction is vested-ie., it recognizes that the conflict of laws, like every other branch of private law, forms part and parcel of a municipal system of laws.

\footnotetext{
${ }^{117}$ Infra $58 \mathrm{I}-605$.
}

${ }^{218}$ Id. at 602 . 
To appreciate this fully, it is necessary to realize that the modern vested right theory is a considerably modified version of the former unqualified theory of that name.

\section{The Unqualified Vested Rights Theory.}

It is beyond the compass of this paper to examine historically whether the older authors and the judges in older English decisions, when propounding that a right duly acquired under the law of another country should be protected in England, thought that such right could, proprio vigore, claim enforcement in the English jurisdiction.

It cannot be denied that several dicta in English decisions ${ }^{119}$ and the statement of principle in Dicey, which remained unaltered from the first to the fifth edition, lends some color to that view. Thus, it is stated in the fifth edition of Dicey, as General Principle No. 4, that ${ }^{120}$

... any right which has been fully acquired under the law of any civilised country is recognised, and, in general, enforced by English law.

However, it should not be overlooked that some of the older authors made considerable reservations when stating this theory: they apparently never denied that it was English law which had to decide whether or not a right was "duly acquired." Thus, in his General Principle No. 5, Dicey, in the fifth edition, distinguishes between the "type" and the "incidents" of a right and states that "the type" of the right is to be recognized by English law (the lex fori), whereas the characterization of "the incidents" is left to the lex causae. ${ }^{121}$ In view of this distinction, it might at least be regarded as doubtful whether Dicey himself accepted the unqualified vested rights theory.

\section{The Modern Vested Rights Theory.}

Those adhering to the modern vested rights theory have further emphasized the influence of the lex fori in the determination of the vested right. This will be seen if the preceding statement in Dicey's first five editions is compared with the following statement of the vested rights theory in the sixth edition, which states, as General Principle No. I: $:^{122}$

Any right which has been acquired under the law of any civilised country which is applicable according to the English rules of the conflict of laws is recognised and, in general, enforced by English courts, and no right which has not been acquired in virtue of an English rule of the conflict of laws is enforced or, in general, recognized by English courts.

${ }^{119}$ E.g., Turner, L. J., in Hooper v. Gumm, L. R. 2 Ch. 282,289 (I867); Maugham, J., in Re Askew, [1930] 2 Ch. 267; see further, Duff, J., in the Canadian case of Livesley v. Horst Co., [1924] S. C. Rep. (Can.) 605, quoted with approval by Pilcher, J., in J. D'Almeida Aruajo Ltd. v. Sir Frederick Becker \& Co., [1953] 2 Q. B. 329.

${ }^{200}$ Albert V. Dicey, Conflict of Laws i7 (5th ed. 1932).

${ }^{121} \mathrm{Id}$. at 43 .

${ }^{122}$ DiceY, op. cit. supra note 76 , at i (emphasis added). 
The present writer stated elsewhere ${ }^{123}$ that the essence of the principle is that, ... as a matter of justice the municipal courts should recognise and give effect to rights which, in their judgment, a person has duly acquired under any system of law, municipal or foreign.

The difference between the old and the new vested rights theories is, thus, that the new vested rights theory recognizes that it is ultimately for the lex fori to determine whether a right alleged to have been acquired under a foreign legal system has really been so acquired. According to the unqualified vested rights theory, the lex for i is invoked once only-namely, after the determination of the right as "vested," when the question of public policy arises; but according to the modern rested rights theory, the lex fori is invoked twice: first, when the question arises whether the right is to be regarded as "vested"- - this question is decided by the lex fori in conjunction with the lex causae $e^{124}$-and secondly, when the question arises whether the public policy of the forum admits such vested right, a question which falls to the lex fori alone for decision. The important modification which the modern vested rights theory admits is, to a large extent, the result of the teaching of Cook, and in so far, his contribution to the theoretical foundation of the conflict of laws is readily acknowledged by the representatives of that theory.

Beyond that, however, they are unwilling to go. They believe that, in spite of two world wars and a recent resurgence of excessive legal nationalism evinced by a theoretical ${ }^{125}$ and practical ${ }^{126}$ extension of the principle of territoriality, a sufficient similarity of fundamental legal concepts is still left in the world to admit the idea that at least some great principles of law are found in most of these systems and rights resulting from them should be protected by municipal jurisdictions. It has been written elsewhere: ${ }^{127}$

Those supporting the vested rights theory . . . believe that such a principle exists and that it is ultimately founded on the idea that there exist human rights which should be recognised and protected by the courts of all civilised countries, subject to the exigencies of municipal public policy. By proclaiming the Universal Declaration of Human Right and by adopting the Convention of Human Rights, the United Nations have made an attempt to provide some degree of protection for such rights in the international sphere; although in the municipal sphere these attempts cannot be called in aid of the argument in favor of the vested rights theory, it is believed that they are founded on the same conception of justice from which the doctrine of the vested rights arose in the Anglo-American conflict of laws.

${ }^{223}$ Schmitrhoff, op. cit. supra note 8, at 33 (emphasis added).

${ }^{224}$ See Schmitthoff, op. cit. supra note 8 , at 38 .

${ }^{125}$ Sce Niboyet, Territoriality and Universal Recognition of Rules of Conflict of Laws, 65 Harv. L. Rev. 582 (1952).

${ }^{220}$ Bank voor Handel v. Slatford, [195I] 2 All. E. R. 779; Camille and Henry Dreyfus Foundation, Inc. v. Inland Revenue Comm'rs, [1955] 3 Weekly L. R. 45I. The argument of the Crown in Re Azoff-Don Commercial Bank, [1954] Ch. 315, was fortunately rejected by Wynn-Parry, J.

${ }^{237}$ SchmitrhoF, op. cit. supra note 8 , at 34 . 


\section{Recognition of the Importance of the International Element}

That a positive municipal system of conflict norms which will give its due place to conflict avoidance has to admit an international element into its theoretical frame is recognized by some modern representatives of the local rights theory. Thus, Professor Lederman, who himself accepts the local rights theory, states that, nevertheless, the vested rights theory ${ }^{128}$

... does assert correctly what must be the basic policy and purpose of any conflictual system-that persons involved in international situations of fact should be able to enjoy the same legal relations in all countries touched by these facts.

Professor Lederman accepts the local rights theory de lege lata and advocates the vested rights theory de lege ferenda, and-and this is the important point-does not consider the two as dogmatically irreconcilable. In his view, the local rights theory is a correct analysis of conflict systems at the present time, but the vested rights theory is the desirable foundation for the future conflict development. However, if he thinks that the vested rights theory is identical with a demand for uniformity of the law, he overrates the degree of internationalism contained in that theory. To those supporting the vested rights theory, uniformity of law is just the same as to those supporting the local rights theory-namely, as Professor Lederman aptly puts it, "the great desideratum"-but they realize fully that it is not yet reality and, as a comprehensive scheme of conflict avoidance, might hardly become reality for some time to come.

However, that conflict avoidance is practiced not only on the international, but extensively likewise on the private level appears to them to support the view that a modicum of common understanding on fundamental legal concepts is still left in the world and is capable of extension. That is a sufficient basis on which to build, at the present time, a modern vested rights theory, with its hopeful implications.

Professor Lederman, like the present writer, attempts to find a synthesis between the extremely national contents of the local rights theory and the moderately international contents of the vested rights theory, and, although they approach the problem from different sides, the gulf appears almost to be bridged.

It is significant that Professor E. W. Briggs, approaching the problem from a different and highly original angle, likewise suggests a theory under which "national interests ... . are recognised without surrendering the ideal of an ultimately genuine universal system of laws." 129

\section{Outlook}

If conflict avoidance in all its implications is recognized as a corollary to conflict solution, does not the dispute between the conflicting theories of the subject lose much of its significance? Are we not in a similar cul de sac to that in which the

\footnotetext{
${ }^{128}$ Lederman, Confict Avoidance by International Agrecment, infra 581, 602.

${ }^{123}$ Briggs, The "Legislative Jurisdictional Principle," in a Policy-Centered Conflict of Latus, 4 INT'L \& CoMP. L. Q. 329, 355 (1955).
} 
statutists found themselves when disputing the values of the personal and real statutes? In conflict avoidance, we have a great discipline founded on the existence of similarities between the legal systems of the world, a practical science which, in a workmanlike fashion, uses the only method which in the second half of the twentieth century can advance the science of the conflict of laws, namely, the comparative method.

It is essential that the conflict of laws systems everywhere should be retrieved from the narrow compass of nationalism which limited them in the nineteenth and the first half of the twentieth century and should, as in the eighteenth century, again be seen in their intimate functional relationship to international commercial law. This can only be done by the extensive use of the comparative method. The planner of international transactions who is engaged in conflict avoidance uses this method already in our days; it is the method of the future in global conflict relations. This, in due course, will completely alter the theoretical bases of the subject: the comparative method, with its broad international implications, will indicate the way out of the cul de sac in which the theoretical discussion has placed the subject at present. One day, we may perhaps say with respect to the theories of local and vested rights: "cela est bien dit, mais il faut cultiver notre jardin."

\section{IV}

\section{Conclusions}

r. Two approaches are possible to problems of the conflict of laws: the preventive method of conflict avoidance and the clinical method of conflict solution by the courts or statute.

2. Traditionally, the conflict in the common-law countries is founded on the rules of conflict solution.

3. Conflict avoidance is a subject of growing importance, in view of the general political and economic conditions of the post-war era.

4. Conflict avoidance can be pursued on the international, national, and private levels.

5. On the international level, conflict avoidance aims at the unification of law by international agreement of governments or the adoption of common practices sponsored by nongovernmental international bodies.

6. On the national level, conflict avoidance aims mainly at the avoidance of an internal conflict between several legal systems under the jurisdiction of the same sovereign and the maintenance of uniform interpretation of international agreements.

7. Conflict avoidance on the private level can be practiced in fields in which the autonomy of the parties applies, notably in the law of contract, but also in other areas, such as inter vivos trusts of movables, succession planning, the choice of the forum, and the international organization of corporate business.

The extent of autonomy and the restrictions of public policy vary in the various countries and are important factors in the planning of international transactions. 
8. Avoidance has to be distinguished from evasion. A choice-of-law clause which is not bona fide and the use of the "quasi-foreign" corporation are illustrations of evasive devices in the conflict of laws.

9. The localization of a legal transaction in a municipal jurisdiction is carried out by total or partial localization devices.

10. Illustrations of total localization devices are the confirmation of a commercial transaction by a banker's confirmed credit or by a confirming house, and the use of a foreign subsidiary which is controlled by a parent corporation in another jurisdiction.

A modern tendency is to avoid conflicts by adopting rules of international lawe.g., an international corporation adopts a statute intended to submit it, in all respects, to its own law.

Ir. Illustrations of partial localization devices are choice-of-law and arbitration clauses.

x2. Theoretically, the subject of conflict avoidance assumes the existence of a measure of agreement on fundamental legal principles amongst civilized nations.

The subject of conflict avoidance is founded on the comparative legal method, and this approach enables a synthesis of the theories of local and vested rights; the comparative method is the method of the future in global conflict relations. 